\title{
The German "Verständigung” and Consensual Elements in German Criminal Trials
}

\author{
Matthias Jahn* and Charlotte Schmitt-Leonardy**
}

(Accepted 13 November 2019)

\begin{abstract}
Negotiated agreements in criminal proceedings have often been regarded as the embodiment of a negative wider trend towards the informalization of the criminal procedure, and have-especially in Germany-long been the subject of vivid controversies. A criminal proceeding in the traditional sense aims to establish the truth ex officio, which is achieved by means of a comprehensive inquiry into the facts conducted by the court during the trial, followed by a sentence that appropriately reflects the individual guilt of the defendant, which can then, in turn, achieve the procedural objective of "justice." A streamlining of the extensive inquiry into the facts that the court would normally have to conduct via the consensual process of negotiation does not, a priori, fit the mold of a criminal procedure in the aforementioned sense. At the same time, the consensual termination of criminal proceedings - which also includes other forms of termination of the proceeding besides the concept of Verständigung, which occur by means of a preferment of public charges-is, in fact, more prevalent in practice these days than judgments rendered in adversarial trials are. Our Article focuses on the reasons why this stark contrast between legal doctrine and reality came to pass and which aspects of the implementation of the concept of consensus into the German law of criminal procedure still seem problematic.
\end{abstract}

Keywords: Negotiated agreements; criminal proceedings; informalization; truth; reform of the criminal procedure

\section{A. Introduction}

In Germany, "negotiated agreements" in criminal proceedings have often been regarded as the embodiment of a negative, wider trend towards the informalization of the criminal procedure. This is why they have long been referred to as "deals" — a term which, at least to a German jurist, evokes the image of a sell-off of justice ${ }^{1}$ for the sake of time-saving at all costs. ${ }^{2}$ The traditional idea

\footnotetext{
${ }^{*}$ Matthias Jahn holds the Chair for criminal law, law of criminal procedure, corporate crime law and legal theory at Goethe University of Frankfurt, Germany. He also serves as a full-time Judge at the Higher Regional Court (Oberlandesgericht) Frankfurt, the highest court of appeal in criminal matters in the State of Hessia.

${ }^{* *}$ Dr. Charlotte Schmitt-Leonardy is a Senior Research Assistant at the Institute for Criminal Sciences and Legal Philosophy (Chair of Prof. Dr. Matthias Jahn) at the Goethe-University of Frankfurt, Germany, and is Co-Editor of the Law Journal Wistra. She currently teaches as a stand-in professor at the University of Heidelberg.

This Article is in part based on a speech delivered by the authors at the conference of the Rijksuniversiteit Groningen titled "Dealen met ondermijningsdelicten" ("Dealing with organised/financial/drug crime") which took place on February 21, 2019 in The Hague, Netherlands. The authors would like to thank Jacob Henze for his invaluable help with the translation of this article into the English language.

${ }^{1}$ See Bundesverfassungsgericht [BVerfG] [Federal Constitutional Court] Jan. 27, 1987, 40 NEUE JURISTICHE WOCHENSCHRIFT [NJW] 2662 (2663), 1987 (Ger.).

${ }^{2}$ See Matthias Jahn \& Hans Kudlich, in 2 Münchener Kommentar ZUR Strafprozessordnung $\$ 257 \mathrm{c}$ margin no. 5, 9 (Hartmut Schneider et al. eds., 2016).
}

(C) The Author(s), 2020. Published by Cambridge University Press on behalf of the German Law Journal. This is an Open Access article, distributed under the terms of the Creative Commons Attribution licence (http://creativecommons.org/licenses/by/4.0/), which permits unrestricted re-use, distribution, and reproduction in any medium, provided the original work is properly cited. 
behind this perspective is as follows: A criminal proceeding aims to establish "the truth," proprio $m o t u$, which is achieved by means of a comprehensive inquiry into the facts conducted by the court during the trial, followed by a sentence that appropriately reflects the individual guilt of the defendant (known as the principle of Schuldangemessenheit), which can then, in turn, achieve the procedural objective of "justice."3

A streamlining of the extensive inquiry into the facts that the court would normally have to conduct, effected via the consensual process of negotiation, does not, a priori, fit the mold of a criminal procedure in the aforementioned sense. At the same time, the consensual termination of criminal proceedings is more prevalent in practice these days than judgments rendered in adversarial trials. ${ }^{4}$ This Article focuses on how this stark contrast between legal doctrine and reality came to pass, why German criminal law scholars prefer the term "negotiated agreement" to the word "deal" with all its pejorative connotations, and which aspects of the implementation of the concept of consensus into the German law of criminal procedure are still viewed as problematic.

\section{B. Informal Practices—Formalization-New Tendencies towards an Informalization of Criminal Procedure}

\section{From Practice to Law ${ }^{5}$}

The practice of negotiating agreements with a view to the termination of criminal proceedings (Verständigung in German) only received a direct democratic legitimization in the Law on July 29, 2009 (the Verständigungsgesetz, which translates to "Law Governing Negotiated Agreements in Criminal Proceedings."). ${ }^{6}$ It is fair to say that this parliamentary legitimization after the fact is an illustrative example of what the Austro-German jurist Georg Jellinek ${ }^{7}$ meant $^{2}$ when he uttered his famous observation on the "normative force of the factual" (die normative Kraft des Faktischen). That is to say, the normative force that emanates from nothing more than the actual present state of affairs, rather than from a law. The Verständigungsgesetz was the codification of a practice that had remained controversial, even as it had become more and more widespread. Given that we are dealing with a mere practice, it is difficult to pinpoint its exact origins. Still, it seems plausible - for a variety of reasons - that the informal negotiation of agreements in criminal proceedings had been taking place for many decades before it was eventually explicitly legalized. ${ }^{8}$ Not least of all, this has to do with the introduction in 1974 of Section 153a of the

\footnotetext{
${ }^{3}$ Hans Kudlich, Konsens und Gerechtigkeit? - Konsens und Gerechtigkeit!, in FESTSCHRIFT FÜR ReINHOLD SCHLOTHAUER 333, 334 (Stephan Barton et al. eds., 2018) (“ $\$ 244$ Abs. 2 StPO und $₫ 46$ StGB werden damit zu Garanten eines auch gerechten Urteils, und Wahrheitsermittlung und Gerechtigkeit bilden dabei die zentralen, miteinander kombinierten Verfahrensziele.”).

${ }^{4}$ See Statistisches Bundesamt (Destatis), Strafgerichte — Fachserie 10 ReiHe 2.3, 28, 66 (2018) https:/www.destatis.de/ DE/Themen/Staat/Justiz-Rechtspflege/Publikationen/Downloads-Gerichte/strafgerichte-2100230187004.pdf?_blob=publicationFile [hereinafter Strafgerichte — FACHSERIE 10 ReiHe 2.3]; Statistisches BundeSAMT (Destatis), Strafgerichte — FaCHSERIE 10 REIHE 2.6, 26 (2017) https:/www.statistischebibliothek.de/mir/servlets/MCRFileNodeServlet/DEHeft_derivate_00040935/21002601 77004.pdf;jsessionid=07686F64F9F275638BA56722752B14D9 [STRAFGERICHTE — FACHSERIE 10 REIHE]; Arbeitskreis AlternativEntwurf (2019), Alternativ-Entwurf: Abgekürzte Strafverfahren im Rechtsstaat (AE-ASR), in GOLTDAMMER'S ARCHIV FÜR STRAFRECHT 1, 4 (2019).

${ }^{5}$ See also Charlotte Schmitt-Leonardy, Verständigung als gelungene Strategie im Umgang mit Informalisierungstendenzen im Strafverfahren?, 3 KRIMINOLOGISCHES J. 213, 215-16 (2019).

${ }^{6}$ Gesetz zur Regelung der Verständigung im Strafverfahren [Law Regulating Understanding in Criminal Proceedings], July 29, 2009, BGBL. I at 2353, *https://www.bgbl.de/xaver/bgbl/start.xav\#_bgbl_\%2F\%2F*\%5B\%40attr_id\%3D\%27bgbl109s 2353.pdf\%27\%5D_1593979371699 (Ger.).

${ }^{7}$ See Georg Jellinek \& Walter Jellinek, Allgemeine Staatslehre 338 (3d ed. 1921).

${ }^{8}$ See Matthias Jahn \& Barbara-Luise Bendrick, Wie es wurde, was es ist - Die Ursprünge der Absprachen im deutschen Strafverfahren vor 1982 unter besonderer Berücksichtigung des Wirtschaftsstrafprozesses, 38 ZEITSCHRIFT FÜR NEUERE RECHTSGESCHICHTE 261 (2016) (explaining the history of "deal” prior to 1982).
} 
German Code of Criminal Procedure (the Strafprozessordnung), ${ }^{9}$ a provision that allows prosecutors to dispense with the preferment of public charges in exchange for the accused's compliance with conditions or other instructions imposed by the prosecution with the approval of the court and the accused. ${ }^{10}$

Consequently, the argument that an informalization of criminal proceedings is tantamount to their simplification, which, in turn, leads to an "increase of the efficiency and rationality of criminal law by reducing costs," 11 attracted a steadily growing level of attention. The maintenance of the "functionality of the criminal justice system" has even come to be viewed as a constitutionally protected parameter, "without [which] justice cannot be achieved." 12

Legal scholars in Germany have viewed the phenomenon of informal agreements in criminal proceedings with deep suspicion from the very beginning. Critics warned that it would inevitably lead to the "irreversible destruction of the liberal, rule of law-based criminal procedure"13 and ultimately prove to be the gateway through which criminal proceedings would degenerate into an "undignified form of operatic theatre." 14 But despite its emphatic rejection by some members of the academic community, the informal practice gradually became part of the day-to-day procedural reality. ${ }^{15}$ It was not until 1997 that the Federal Court of Justice (Bundesgerichtshof) - the highest court of appeal in criminal matters-made an attempt to develop, through its case law, a set of "procedural rules governing negotiated agreements"16 applicable in criminal trials. But only after a "cry for help" ${ }^{17}$ by the Federal Court of Justice's Grand Criminal Panel ${ }^{18}$ several years later did this discussion finally lead to the passing of the aforementioned Verständigungsgesetz of July 29, 2009- one of the most profound changes to the German Code of Criminal Procedure since its entry into force on October 1, 1879, almost 140 years ago. ${ }^{19}$ Since the judgment rendered by the

\footnotetext{
${ }^{9}$ Strafprozessordnung [StPO] [CODE OF CRIminal Procedure], $\$ 153 \mathrm{a}$, translation at https://www.gesetze-im-internet. de/englisch_stpo (Ger.).

${ }^{10}$ See Einführungsgesezt sum Strafgesetzbuch [EGStGB] [Introductory Act to the Criminal Code], Mar. 9, 1974 BGBL. I at 469, (Ger.); Bundesgerichtshof [BGH] [Federal Court of Justice] July 11, 1978, 28 ENTSCHEIDUNGEN DES BUNDESGERICHTSHOFES IN STRAFSACHEN [BGHST] 69 (70), 1978 (Ger.); Herbert Diemer, in KARLSRUHER KOMMENTAR STOP, \$ 153a margin no. 3 (8th ed. 2019) ("Beendigungsverfahren mit Selbstunterwerfung.").

${ }^{11}$ Hans-Jörg Albrecht, Rechtsstaatliche Möglichkeiten der Vereinfachung des Strafverfahrens, in VON TOTALITÄREM ZU RECHTSSTAATLICHEM STRAFRECHT, 557-77 (Albin Eisner et al. eds., 1993).

${ }^{12}$ Bundesverfassungsgericht [BVerfG] [Federal Constitutional Court] Dec. 15, 1965, 19 EnTsCHEIDUNGEN DES BundesverfassungSGERICHTS [BVERFGE] 342 (347), 1965 (Ger.); Bundesverfassungsgericht [BVerfG] [Federal Constitutional Court] May 3, 1966, 20 EntscheIdungen DES Bundesverfassungsgerichts [BVERFGE] 45 (49), 1966 (GER.); Bundesverfassungsgericht [BVerfG] [Federal Constitutional Court] July 7, 1966, 20 ENTSCHEIDUNGEN DES BundESVERFASSUNGSGERICHTS [BVERFGE] 144 (147), 1966 (GER.); Bundesverfassungsgericht [BVerfG] [Federal Constitutional Court] July 19, 1972, 33 ENTSCHEIDUNGEN DES BundESVERFASSUNGSGERICHTS [BVERFGE] 376 (383), 1972 (GER.).

${ }^{13}$ Bernd Schünemann, Wohin treibt der deutsche Strafprozess?, 114 ZEITSCHRIFT FÜR DIE GESAMTE STRAFRECHTSWISSENSCHAFT 1, 53 (2002).

${ }^{14}$ Werner Schmidt-Hieber, Der strafprozessuale "Vergleich" - eine illegale Kungelei?, in STRAFVERTEIDIGER 355, 355 (1986).

${ }^{15}$ See generally Matthias Jahn \& Martin Müller, Der Widerspenstigen Zähmung - Aktuelle Gesetzgebungsvorschläge zu den Urteilsabsprachen im Strafprozess, 38 JURISTISCHE ARBEITSBLÄTTER 681 (2006) [hereinafter Jahn \& Müller, Der Widerspenstigen Zähmung]; Matthias Jahn \& Martin Müller, Das Gesetz zur Regelung der Verständigung im Strafverfahren - Legitimation und Reglementierung der Absprachepraxis, 62 NeuE JuRISTISCHE WOCHENSCHRIFT 2625 (2009) [hereinafter Jahn \& Müller, Das Gesetz zur Regelung].

${ }^{16}$ Bundesgerichtshof [BGH] [Federal Court of Justice] Aug. 28, 1997, 43 ENTSCHEIDUNGEN DES BUNDESGERICHTSHOFES IN STRAFSACHEN [BGHSt] 195 (201), 1997 (Ger.).

${ }^{17}$ Helmut Satzger, Absprachen im Strafprozess, Wirksamkeit eines abgesprochenen Rechtsmittelverzichts, Anmerkung zum Beschluss (GS) des BGH vom 3.3.2005, 37 JuRISTISCHE ARBEITSBLÄTTER 684, 686 (2005).

${ }^{18}$ See Bundesgerichtshof [BGH] [Federal Court of Justice] Mar. 3, 2005, 50 ENTSCHEIDUNGEN DES BundesGERICHTSHOFES IN STRAFSACHEN [BGHSt (GrS)] 40 (63), 2005 (Ger.). Cf. Hans Kudlich, Erfordert das Beschleunigungsgebot eine Umgestaltung des Strafverfahrens?, Gutachten C zum 68. Deutschen JuRISTEnTAg 2010, at C 37.

${ }^{19}$ See Jahn \& Müller, Der Widerspenstigen Zähmung, supra note 15, at 682.
} 
Federal Constitutional Court (Bundesverfassungsgericht) on March 19, 2013, ${ }^{20}$ it has been firmly established that the consensual termination of criminal proceedings as envisaged by the Verständigungsgesetz is, in principle, in conformity with the German constitution.

\section{Formalizing the Informal}

What constitutes a negotiated agreement is not explicitly defined in German law. The term denotes the termination of a legal proceeding by virtue of a binding procedural agreement about the further course and the outcome of the proceeding.

Furthermore, it follows from the legislative materials that accompany the Verständigungsgesetz that the consensus of the parties does not form the only basis of the judgment-which is also why the law does not contain terms like "deal" or "settlement" - because a quasi-contractually binding commitment was precisely what lawmakers did not want to create. ${ }^{21}$ Accordingly, the Verständigung constitutes a sui generis procedure, which constitutes quite the paradigm shift, as far as criminal proceedings in the first instance are concerned. At the same time, in principle, it is supposed to be accepted as an equal and equivalent method of formally resolving social conflicts by means of criminal proceedings besides traditional adversarial proceedings. ${ }^{22}$ As the language of Section 257c paragraph 1 of the German Code of Criminal Procedure-mentioning "an agreement with the participants"-indicates, the Verständigung is a participatory procedure wherein the potential legal consequences of the judgment and the associated rulings, the conduct of the participants during the trial, as well as other procedural measures related to the underlying adjudicatory proceedings - by way of a catch-all clause-may be discussed. ${ }^{23}$

Such agreements are typically made possible by a defendant's confession. ${ }^{24}$ The defendant and the court enter into the agreement, with the approval of the prosecution, where the objective is the shortening of the factual inquiry the court has to conduct. This is where the main problems associated with negotiated agreements lie.

\section{Squaring the Circle}

In contrast to the Anglo-American approach to criminal procedure, where plea bargaining between the defense and the prosecution is regarded as a key component of the proceeding, under German law, the court is firmly in the driving seat throughout the negotiation process leading up to the eventual agreement. ${ }^{25}$ This follows directly from the wording of Section $257 \mathrm{c}$ paragraph 1 of the German Code of Criminal Procedure, "with the participants," 26 but also from the fact that it is the court pursuant to Section $257 \mathrm{c}$ paragraph 3, that announces the "content that the negotiated agreement could have." ${ }^{27}$ Moreover, it is the court that can indicate both a minimum and a maximum sentence, by which it is then-save for exceptional circumstances-bound argumentum e contrario. ${ }^{28}$

\footnotetext{
${ }^{20}$ Bundesverfassungsgericht [BVerfG] [Federal Constitutional Court] Mar. 19, 2013, 133 EnTSCHEIDUNGEN DES BundESVERFASSUNGSGERICHTS [BVERFGE] 168, 2013 (Ger.).

${ }^{21}$ See Regierungsentwurf [Cabinet Draft], DeUTSCHER BundeSTAG: DruCKSACHEN [BT] 16/12310, https://dip21.bundestag. de/dip21/btd/16/123/1612310.pdf (Ger.) [hereinafter Cabinet Draft 16/12310]; See also Jahn \& Kudlich, supra note 2, at $\$ 257 \mathrm{c}$ margin no. 60 with further references.

${ }^{22}$ Jahn \& Kudlich, supra note 2 , at $\$ 257 \mathrm{c}$ margin no. 1 .

${ }^{23} \mathrm{STPO} \$ 275 \mathrm{c}$, para. 2 , sentence 1 .

${ }^{24}$ See Jahn \& Kudlich, supra note 2 , at $\$ 257 \mathrm{c}$ margin no. 60 .

${ }^{25}$ Thomas Weigend, Verständigung in der Strafprozessordnung - auf dem Weg zu einem neuen Verfahrensmodell?, in Gerechte Strafe und legitimes Strafrecht: Festschrift für Maiwald zum 75. Geburtstag 833 f. (R. Bloy et al. eds., 2010).

${ }^{26} \mathrm{STPO} \$ 275 \mathrm{c}$, para. 1 .

${ }^{27} I$ d. $\$ 275$ c, para. 3 , sentence 1 .

${ }^{28} I d$.
} 
The judge thus serves as a "gatekeeper"29 for the negotiating process. It is he or she who opens the gate for that process in the first place and who is involved in the negotiations in a key capacity. Where the negotiations fail, it also falls to the judge to render a judgment in an adversarial, which is to say nonconsensual, trial.

Furthermore, according to the legislative materials that accompanied the Verständigungsgesetz, the basic pillars of the German criminal procedure are supposed to remain unaffected by the implementation of the possibility to terminate criminal proceedings by mutual consent. In particular, the Verständigungsgesetz is not supposed to be viewed as a recognition of consensus as a new procedural maxim ${ }^{30}$ that would constitute a legitimatization. ${ }^{31}$ For if the court's duty to establish the facts of the case of its own motion as it has historically been understood truly remained unaffected by the 2009 reform, as the legislative materials to the Verständigungsgesetz suggest, a negotiated agreement would only come into play once all avenues of the "inquiry into objective facts which is only restricted by the limits of human comprehension" 32 have been exhausted. If this was indeed the case, there would be only a very narrow scope of application for negotiated agreements. Nevertheless, German legal doctrine steadfastly insists on the Prussian idea of an inquisitorial discovery of the truth. Still, the notion of a modified interpretation of the inquisitorial approach that would recognize the consensus maxim as a basis from which legitimation could be derived has, by and large, not been entertained yet.

\section{Truth by Consensus?}

The search for the truth in criminal proceedings, which, as a person familiar with German procedural law once sarcastically remarked, is akin to "a buried piece of gold," 33 is constructed along the lines of a vertical model that revolves around the court. It follows that it is largely independent from the negotiating skills of the parties to the proceeding. ${ }^{34}$

Pursuant to the majority view among legal scholars, ${ }^{35}$ the truth that Section 244 paragraph 2 of the German Code of Criminal Procedure refers to, and that the criminal procedure as a whole ultimately strives towards, is conceptually based on the understanding of truth as advanced by the correspondence theory of truth. According to this view, the truth is the congruence of a realization with facts outside of that realization-in other words, the correspondence, or congruence, between ideas and reality-in the vein of the classical interpretation à la Aristotle ${ }^{36}$ and the famous phrase "adaequatio intellectus et rei." ${ }^{37}$ It is precisely this conceptualization of the content and purpose of truth that is, and has been-since its affirmation by the Reichsgericht, the

\footnotetext{
${ }^{29}$ Franz Salditt, Ermessen - Zum Richterbild des Verständigungsgesetzes, in FESTSCHRIFT FÜR TOLKSDORF $377,383 \mathrm{f}$.

(Friedrich Dencker et al. eds., 2014).

${ }^{30}$ See Matthias Jahn, Die Konsensmaxime in der Hauptverhandlung, 118 ZEITSCHRIFT FÜR DIE GESAMTE StrafreCHTSWISSENSCHAFt 427, 460 (2006); Hans Theile, Wahrheit, Konsens und $\$ 257 c$ StPO, 32 NeUE ZEITSCHRIFT FÜr STRAFRECHT 666 (2012).

${ }^{31}$ See Cabinet Draft 16/12310, supra note 21.

${ }^{32}$ Matthias Jahn, Das heutige Ermittlungsverfahren aus Sicht von Wissenschaft und Justiz - die Entwicklung in den letzten drei Jahrzehnten und die rechtspolitischen Baustellen, in WIDER DIE WILDWÜCHSIGE ENTWICKLUNG DES ERMitTlungsverfahrens, 35, 38 (Stephen Barton, Ralf Kölbel \& Michael Lindemann eds., 2015).

${ }^{33}$ Klaus Volk, Konfliktverteidigung, Konsensualverteidigung und die Strafrechtsdogmatik, in FESTSCHRIFT FÜR DAHS 496 (2005).

${ }^{34}$ See generally Gerson Trüg, Erkenntnisse aus der Untersuchung des US-amerikanischen plea bargaining-Systems für den deutschen Absprachendiskurs, 120 ZEITSCHRIFT FÜR DIE GESAMTE STRAFRECHTSWISSENSCHAFT 331, 334 (2008), https://www. degruyter.com/view/journals/zstw/120/2/article-p331.xml.

${ }^{35}$ See Heinz Müller-Dietz, Der Wahrheitsbegriff im Strafverfahren, 15 ZEITSCHRIFT FÜR EvANGELISCHE ETHIK 257, 257 (1971); Ulfrid Neumann, Wahrheit im Recht: Zu Problematik und Legitimität einer fragWürdigEN DENKForm 73 (2004); Frauke Stamp, Die Wahrheit im Strafverfahren 37 (1998); See also Theile, supra note 30, at 666; Trüg, supra note 34 , at 334 .

${ }^{36}$ Aristotle, MetaphysiK, bk. IV at 1011 b (2d ed., Hofenberg 2016) (c. 350 B.C.E.).

${ }^{37}$ Thomas Aquinas, Summa Theologiae, qu. 1, art. 16 ad 2 (Kerle et al. eds., Heidelberg 1933) (c. 1225-1274).
} 
predecessor of the Federal Court of Justice as the highest court of appeal in criminal matters until 1945-prevalent in German criminal law doctrine. As the Reichsgericht put it: "The objective of the criminal proceeding is to find justice. This objective can only be achieved, if the proceeding is grounded in truth." 38 This has given rise to the idea that a criminal judge is a "historian" 39 of sorts, who is in a position to uncover "the one truth" unimpeded by any empirical or normative restrictions.

But this view has been the subject of nuanced criticism for a while now, ${ }^{40}$ which has questioned whether the material truth really exists and, if so, whether it can, and may, be investigated, both in general and with the means that are available in criminal proceedings in particular. In the affirmative, are there any restrictions on the absolute search for the material truth? ${ }^{41}$

The first question, whether the material truth exists, has-as Weigend puts it— "occupied theologians, philosophers, and lawyers for quite some time, and agreement has yet to emerge." 42 It is a fundamental question ${ }^{43}$ that has found, inter alia, pragmatic answers as given by the theories of truth, developed by Peirce and subsequently significantly refined by James and Dewey. ${ }^{44}$ Those concepts have moved away from defining the notion of truth in the abstract. Instead, the pragmatists view the truth as a regulative principle governing the examination of beliefs or convictions. ${ }^{45}$ Statements that purport to have a universal validity are viewed as pointless. Instead, the focus of the proponents of the pragmatic theories of truth is on the practical meaning, which has to be justified in the eyes of a certain audience. ${ }^{46}$ Pursuant to this view, it is unnecessary to look for a relationship to reality or something called the truth, if a statement of fact is met with approval from a competent audience. This understanding of truth as a "warranted assertibility" 47 also provides the basis for lines of reasoning that are rooted in the consensus theory of $\operatorname{truth}^{48}$ and

\footnotetext{
${ }^{38}$ Reichsgericht [RG] [Court of Last Resort in Criminal Matters] Apr. 11, 1938, 72 ENTSCHEIDUNGEN DES REICHSGERICHTS IN STRAFSACHEN [RGST] 156 (156) (Ger.).

${ }^{39}$ E. Niethammer, Der Kampf um die Wahrheit im Strafverfahren, in FESTSCHRIFT FÜr SAUER 26,27 (Wilhelm Sauer ed., 2016) (1949).

${ }^{40}$ See also Matthias Jahn \& Charlotte Schmitt-Leonardy, Rechtsphilosophische und straftheoretische Begründungselemente der Verständigung im deutschen Strafverfahren, in STRAFRECHT UND RECHTSPHILOSOPHIE, GEDÄCHTNISSCHRIFT FÜR JOACHIM HRUSCHKA 571 (Joerden \& Schuhr eds., 2019).

${ }^{41}$ See Ulfrid Neumann, Funktionale Wahrheit im Strafverfahren, in DECKER \& MÜlLER, JENSEITS DES FUNKTIONALISMUS 74 (Heinrich Scholler \& Lothar Philipps eds., 1989).

${ }^{42}$ Thomas Weigend, Should We Search for the Truth, and Who Should Do It, 36 N.C.J. INT'L L. \& CoM. REG. 389,394 (2010).

${ }^{43}$ See Michael Moore, The Plain Truth About Legal Truth, 26 HARV. J.L. \& PUb. Pol'y 23, 24,27 (2003) (introducing another differentiation between the existential question about truth and the "mind-independence questions about truth").

${ }^{44} C f$. American Philosophy, John Dewey: Between Pragmatism and Constructivism 195 (Larry A. Hickman, Stefan Neubert \& Kersten Reich eds., 2013).

${ }^{45}$ Compare Charles Sanders Peirce, The Fixation of Belief, Popular SCIEnCE MONTHLy, Nov. 1877, with CharLes SANDERS Pierce, Collected Papers of Charles Sanders Pierce V and Vi: Pragmaticism and Scientific Metaphysics, Vol. 5 , 394 (Charles Hartshorne \& Paul Weiss eds., 1935) ("Truth is that concordance of an abstract statement with the ideal limit towards which endless investigation would tend to bring scientific belief.").

${ }^{46}$ However, the positions of Pierce, Dewey and James differ in their specific manifestations. Cf. WILLIAM JAMES, Pragmatism: A New Name for Some Old Ways of Thinking (Cambridge Univ. Press 2014) (1907); John Dewey, Logic: The Theory of Inquiry (New York: Henry Holt and Company, Jan. 1939); Carl-Friedrich Stuckenberg, Die Erforschung der materiellen Wahrheit im Strafprozess, in DIE STRAFPROZESSUALE HAUPTVERHANDLUNG ZWISCHEN INQUISITORISCHEM UND ADVERSATORISCHEM 42 (Friedrich-Christian Schroeder \& Manuchehr Kudratov eds., 2014) (with further references).

${ }^{47}$ Mo Hayder, John Dewey: zwischen Pragmatismus und Konstruktivismus 169 (Larry Hickman, Stefan Neubert \& Kersten Reich eds., 2004).

${ }^{48} \mathrm{~A}$ further, modern variation of the intersubjective approach is the dialogical, constructivist theory of truth as advanced by the Erlangen School (Erlanger Schule), notably by Kamlah or Lorenzen. Cf. the overview provided in PuNTEL, Wahrheitstheorien in DeR neueren Philosophie: Eine Kritisch-systematische Darstellung 164 (3d ed., Darmstadt: Wissenschaftliche Buchgesellschaft 1993).But in light of the limited space we must leave this line of reasoning to one side, appealing though Erlangen may be as a point of reference.
} 
emphasizes the relationship between the claim to truth and the claim to achieve a consensus of a statement. ${ }^{49}$

Concerning the second set of questions, namely whether and how truth can be investigated, it has long emerged from the German debate that the supposed precision of the notion of truth, as postulated by correspondence theorists, should be rejected with reference to the inherent limits of human comprehension ${ }^{50}$-not least of all explicitly by the Reichsgericht. ${ }^{51}$ Moreover, there has been plausible criticism from the perspective of legal sociology, arguing that the search for the truth, as practiced in criminal proceedings, does not sufficiently take into account the methods and findings of the psychology of testimony by the accused and witnesses. ${ }^{52}$ Such a relativization of the purported absolute value of the truth is also put forward from a normative perspective: The point of reference of the inquisitorial proceeding in the classical sense is merely the "free conviction" gained by the court from the oral hearing as a whole. ${ }^{53}$ That is to say that the applicable law does not envision the search for truth in criminal proceedings to be absolute in nature at all. ${ }^{54}$ Instead, it stipulates a number of restrictive and relativizing parameters, such as the right to apply for the taking of evidence, ${ }^{55}$ as well as the principles on the admissibility or inadmissibility of evidence. In fact, the inherent conflict between the search for the truth and the procedural rights of the defendant is generally decided in favor of the latter ${ }^{56}$ - the truth must not be brought to light at all costs. Therefore, it is only the procedural truth that is reconstructed under the rules of criminal procedure. ${ }^{57}$ This is necessarily asymmetric, as far as the social conflict that underlies the criminal offense is concerned, given that the search for the truth is restricted to facts that are relevant for the criminal offense and penalty. To quote an apt metaphor coined by German criminal law scholar Heinz Müller-Dietz: "The criminal offence [is] a snapshot from the life of the offender: the film as a whole remains underexposed." 58

But if the aspiration towards a supposed absolute truth has thus been "demystified" on the aforementioned argumentative basis, ${ }^{59}$ a return to a discussion about absolute values in the context of the Verständigung, and specifically the argument that the Verständigung naturally leads to "a betrayal of the imperative to strive for truth and justice," 60 seems inexpedient. In fact, the question arises whether it is really the truth that is potentially infringed upon by a consensual

\footnotetext{
${ }^{49}$ See Neumann, supra note 35 , at 24.

${ }^{50}$ See generally Christian Becker, Strafprozessuale Verständigung und philosophische Wahrheitstheorien, in FESTSCHRIFT FÜR Thomas Fischer 603 (Barton et.al. eds., 2018). See also Edda Weßlau, Wahrheit und Legenden: Die Debatte über den Adversatorischen Strafprozess, 9, ZeITSCHRIFT FÜR INTERNATIONALE STRAFRECHTSDOGMATIK 558, 560 (2014).

${ }^{51}$ Reichsgericht [RG] [Court of Last Resort in Criminal Matters] Feb. 15, 1927, 61 ENTSCHEIDUNGEN DES REICHSGERICHTS IN STRAFSACHEN [RGST] 202 (206) (Ger.); Reichsgericht [RG] [Court of Last Resort in Criminal Matters] Mar. 14, 1932, 66 ENTSCHEIDUNGEN DES REICHSGERICHTS IN STRAFSACHEN [RGST] 163 (164) (Ger.).

${ }^{52}$ See Detlef Krauß, Das Prinzip der materiellen Wahrheit im Strafprozeß, in FESTSCHRIFT FÜr FrIEdRICH SCHAFFSTEIN 411, $413 \mathrm{f}$. (Gerald Grünwald et al. eds., 1975).

${ }^{53} \mathrm{STPO} \$ 261$.

${ }^{54}$ See Larry Laudan, Truth, Error and the Criminal Law: An Essay in Legal Epistemology, chs. 2-4 (1st ed. 2008) (illustrating an interesting perspective on the Blackstone's ratio).

${ }^{55}$ See STPO $\$ 244$, paras. 3,4 .

${ }^{56}$ Bundesgerichtshof [BGH] [Federal Court of Justice] June 14, 1960, 14 ENTSCHEIDUNGEN DES BUNDESGERICHTSHOFES IN STRAFSACHEN [BGHSt] 358 (365), 1960 (Ger.).

${ }^{57}$ See Stuckenberg, supra note 46, at 45; Klaus Volk, Diverse Wahrheiten, in FESTSCHRIFT FÜr HANNSKARL SALGER 411,412 (Albin Eser ed., 1995).

${ }^{58}$ See Müller-Dietz, supra note 35 , at 270.

${ }^{59}$ Klaus Lüderssen \& Matthias Jahn, Einleitung Abschnitt M (On the Method of Applying the Law in Criminal Proceedings), in De Gruyter, GroßKommentar ZUR STrafprozessordnung: BAND 1 EINLEITUNG, $\$ \$ 1-47$ (Volker Erb et al. eds., 27th ed. 2016).

${ }^{60}$ Ralf Eschelbach, in BecK’scher OnLINE-KOMMENTAR STPO MIT RiStBV, $\$ 257$ c margin no. 1 (Jürgen Graf ed., 33d ed. 2019); Arndt Sinn, Die Verständigung im deutschen Strafverfahren, in Peter Lang GmbH, Die Strafprozessuale HAUPTVERHANDLUNG ZWISCHEN INQUISITORISCHEM UND ADVERSATORISCHEM MODELL 145, 153 (Friedrich-Christian Schroeder \& Manuchehr Kudratov eds., 2014).
} 
termination of a criminal procedure through a Verständigung within terms of Section $257 \mathrm{c}$ of the German Code of Criminal Procedure. On the one hand, this is because it cannot be ruled out with certainty that a confession made by the defendant corresponds with the truth. There is not even a general rule of thumb, suggesting that confessions that are made as part of a Verständigung are more likely to be untrue than those made in a classic adversarial trial. ${ }^{61}$ On the other hand, Verständigung proceedings - unlike US-style plea bargaining or German civil proceedings - are not based on a "formalized search for the truth." ${ }^{2}$ In other words, they do not revolve around a version of the underlying factual circumstances that is solely determined by the parties and then treated as if it were true if not contested by the parties. ${ }^{63}$ Instead, the facts of the case, as established in the indictment, form the object of a Verständigung. This-even if it always requires a critical evaluation-does not constitute an arbitrary or dispositive starting point pursuant to the German Code of Criminal Procedure standards set out by Section 160 paragraph 2 and Section 170 paragraphs 1 and 2, in conjunction with Section 200 paragraph 1 of the German Code of Criminal Procedure. A "voluntary concurrence of the minds" that is found in this regard "replaces ... to an extent the discovery of truth in an adversarial proceeding, ... but must [at the same time] not conflict with the clear factual and legal situation." ${ }^{\prime 4}$ A consensual termination of proceedings, in that sense, does not imply that a plausible factual basis is discarded as irrelevant. On the contrary, looking at procedural systems that adhere to the adversarial principle, such as those found in common law countries, one could even assume that the antagonistic presentation of competing versions of the truth by each party could be a better strategy for bringing out the most plausible factual base. ${ }^{65}$ In any case, the consensual termination of proceedings could serve as a reasonable disposition about the subject-matter of the proceeding; in other words an agreement on the relevant facts of a social conflict and the treatment thereof, to the extent that it is based on a consensus, which is the embodiment of a voluntary concurrence of the minds.

Nevertheless, upon closer inspection, the discussion around a truth that is threatened by the Verständigung could turn out to be a justified concern about a legitimate consensus, in other words, a consensus characterized by the general possibility of an implausible factual base or latent elements of duress, which makes a version of events the basis of the judgment and puts the legitimacy of the judgment in doubt. This aspect has also emerged out of the parallel debate in common law countries. ${ }^{66}$ The social acceptability of the judgment could be in jeopardy-even if it is based on a consensus between the prosecution and the defense-if there is reason to believe that it is based on a fiction and, thus, fails to resolve the underlying social conflict that triggered the process. ${ }^{67}$

The observation that not just any agreement will suffice-even though there is not any reliable empirical base clarifying the minimum requirements for a criminal judgment to be fair in this sense ${ }^{68}$ - highlights a very important aspect. It is not about the absolute question of finding

\footnotetext{
${ }^{61}$ See Bundesgerichtshof [BGH] [Federal Court of Justice] May 23, 2012, 32 Neue Zeitschrift für Strafrecht [NStZ] 584 (584 f.), 2012 (Ger.); Bundesgerichtshof [BGH] [Federal Court of Justice] May 22, 2014, 67 NEUE JURISTICHE WoCHENSCHRIFT [NJW] 2132 (2133), 2014 (Ger.); Jahn \& Kudlich, supra note 2, at \$257c margin no. 129 (with further references).

${ }^{62}$ Trüg, supra note 34 , at 346.

${ }^{63}$ See Weßlau, supra note 50 , at 559.

${ }^{64}$ BundesRechtSANWALTSKAMMER (BRAK), Vorschlag EINER GESETZlichen Regelung DER URTEILSABSPRACHE IM STRAFVERFAHREN, Stellungnahme Nr. 25/2005, 20 https://brak.de/zur-rechtspolitik/stellungnahmen-pdf/stellungnahmendeutschland/2005/september/stellungnahme-der-brak-2005-25.pdf (emphasis added).

${ }^{65}$ See Weigend, supra note 42 , at 396.

${ }^{66}$ See Tatjana Hörnle, Unterschiede zwischen Strafverfahrensordnungen und ihre kulturellen Hintergründe, 117 ZEITSCHRIFT FÜR DIE GESAMTE STRAFRECHTSWISSENSCHAFT, 801 (2006) (illustrating further insights into other European cultural backgrounds and law traditions).

${ }^{67}$ See Stephanos Bibas, Bringing Moral Values into a Flawed Plea-Bargaining System, 88 CoRnell L. Rev. 1425, 1429 (2003); See also Weigend, supra note 42, at 396; Albert Alschuler, The Changing Plea Bargaining Debate, 69 CAL. L. REV. 652, 704-07 (1981) (underlining the difference between a civil suit and the criminal trial, where the public is involved as an "invisible third party").

${ }^{68}$ See Weigend, supra note 42 , at 390.
} 
the truth, but rather, the process of searching for the truth and its outcome as the relevant factual base of the judgment represents.

From an Anglo-American perspective: "Truth is here subservient to defendant autonomy, or the appearance of it." 69 From German sociologist Niklas Luhmann's point of view, the real purpose that the idea of truth serves might just be the transmission of a reduced complexity via the mechanism of intersubjective certainty. ${ }^{70}$ Based upon the social function of the proceeding, Luhmann argues that the legitimacy of the decision in the sense of a factual recognition of the judgment-rather than the factual accuracy of the judgment-is decisive and explicitly asks the question of "whether uncovering the truth is even the main objective of legally governed proceedings." "11 Yet, in the context of this line of argument, he also emphasizes the "mandatory preservation" of certain perceptions and conclusions ${ }^{72}$ and argues that truth in the sense of a self-evident category also creates a meaning of its own, which "nobody can deny, without at the same time also depriving his opinion of all social relevance and losing every ability to contribute to the debate." ${ }^{\prime 3}$ In other words, "you follow the truth without specific motives-such as sympathy for the decision-makers, recognition of power etc.- purely and simply because of the state of affairs in the world." ${ }^{\prime 4}$ If one moves away from this practice by implementing consensus, new or additional mechanisms conducive to intersubjective certainty may be necessary.

\section{Justice Through Transparency?}

Instead of giving thought to this more nuanced approach to truth and recognizing that the truth cannot be found in the process of appraising a factual matrix, but can only be reconstructed as best as possible in an exceptional case of the legal discourse by suitable procedures, and instead of giving due consideration to the fact that there is only a procedural truth in a criminal proceeding - which takes the shape that is relevant for the criminal punishment in the interplay with provisions of substantive criminal law ${ }^{75}$ - the German legislator decided to take another approach. To make up for the deficits that lawmakers anticipated would be encountered in the "search for the truth," the German legislator did the following: The 2009-law imposed a great amount of transparency obligations implemented in Sections 160b, 202a, 212, 257b, 257c of the German Code of Criminal Procedure and, thus, created a complicated, rules-based negotiation procedure. $^{76}$ In its 2013 constitutional review of the Verständigungsgesetz, the Federal Constitutional Court elevated "the violation of all obligations of transparency and documentation ... to the level of quasi-absolute and absolute grounds for appeal." 77 It has thus created the impression that a deficit in terms of truth and justice in the application of the law — which exists in the FCC's view — can and should be remedied by transparency.

\footnotetext{
${ }^{69}$ Jenny McEwan, Ritual, Fairness and Truth: The Adversarial and Inquisitorial Models of Criminal Trial, in TRIAL ON Trial, Volume 1: Truth and Due Process 51 (Anthony Duff et al. eds., 1st ed. 2004); see also Jacqueline Hodgson, Conceptions of the Trial in Inquisitorial and Adversarial Procedure, in TRIAL ON Trial, Volume 2: JUdGMENT AND CALling to Account 225 (Anthony Duff et al. eds., 1st ed. 2006) ("Within the common law tradition, legal truth is seen as something which is contingent, existing not so much as an objective absolute but as the most plausible or likely account, established after the elimination of doubt.").

${ }^{70}$ See Niklas Luhmann, Legitimation durch Verfahren 23 (1st ed. 1983).

${ }^{71} I d$. at 22 .

${ }^{72}$ Id. at 24

${ }^{73} \mathrm{Id}$. at 24 .

${ }^{74}$ Stuckenberg, supra note 46 , at 51 .

${ }^{75}$ See Winfried Hassemer, FeSTSCHRIFT FÜR KLAus VOLK 214 (Winfried Hassemer et. al. eds., 2009); Theile, supra note 30, at 666; Müller-Dietz, supra note 35, at $260 \mathrm{f}$.

${ }^{76}$ Strafprozessordnung [STPO] [CODE OF CRIMINAL Procedure], $\$ \$ 160 \mathrm{~b}, 202 \mathrm{a}, 212,257 \mathrm{c}$, translation at http://www. gesetze-im-internet.de/englisch_stpo/englisch_stpo.pdf (Ger.).

${ }^{77}$ Carl-Friedrich Stuckenberg, Zur Verfassungsmäßigkeit der Verständigung im Strafverfahren, 8 ZEITSCHRIFT FÜR INTERNATIONALE STRAFRECHTSDOGMATIK 212, 215 (2013).
} 
The Federal Constitutional Court has subsequently even expanded on this position. ${ }^{78}$ This has, in turn, given rise to more restrictive jurisprudence of the Federal Court of Justice- the highest court of appeal in criminal matters - in connection with grounds for appeal which has further developed the transparency obligation into a set of requirements that the criminal justice system can hardly fulfill in day-to-day practice.

The comprehensive documentary requirements - that incidentally also apply even where there is no Verständigung, in the form of the so-called Negativattest, or negative clearance ${ }^{79}$ - come into conflict with the legislative intentions underlying the Verständigungsgesetz. That is to guarantee a practicable normative framework for acceleration and streamlining of the proceedings, along with a higher degree of legal certainty. ${ }^{80}$ This applies, in particular, to the broadening of this approach, pursuant to which the presiding judge's obligation to state whether discussions to conclude a Verständigung ${ }^{81}$ complements the possibility for the trial to be watched by the public and the associated checks and balances over the justice system. The transparency requirements of the Verständigungsgesetz are supposed to help maintain the protection of the defendant against a 'closing of the ranks' between the court, the prosecution and the defense that takes place in secret. In this regard, it has been submitted that it is:

"[I]ncomprehensible and would also lead to an invalidation of the publicity aspect contained in Section 243 paragraph 4 of the German Code of Criminal Procedure, if a violation of the obligation to state [whether a Verständigung took place] was not regarded as an absolute grounds for appeal within terms of Section 338 Nr. 6 of the Code of Criminal Procedure, while it is at the same time also denied that the judgment is based upon a violation of procedural rights pursuant to Section 337 Code of Criminal Procedure with a reference to issues of causation is generally negated the public checks and balances." 82

This would degrade Section 243 paragraph 4 of the Code of Criminal Procedure to the role of a mere procedural order norm.

This strategy of elevating transparency and documentary requirements deserves criticism from the outset. It seems inexpedient to shift the question of compliance with the Verständigungsgesetz to the appeals stage, given that appellate courts can merely review Verständigungen that are affected by mistakes that are so grave shatter the very basis of the consensus. Otherwise, there is no cause for lodging an appeal in the first place. ${ }^{83}$ As former Federal Justice Thomas Fischer once provocatively remarked, it follows that it is not "the worst procedural errors, but the dumbest" that ultimately reach the Federal Court of Justice on appeal. ${ }^{84}$

Furthermore, the fact that these transparency requirements are explicitly distanced from "mere procedural order norms" to elevate them into a set of requirements that is fundamental and that the criminal justice system can hardly live up to in practice anymore has profound effects. Imperceptibly, this perspective changes the basis upon which the legitimacy of the consensus to terminate the proceeding rests. This means that what is regarded as legitimate is what has been adequately documented. It also seems that the argumentum e contrario applies. If the

\footnotetext{
${ }^{78}$ See Bundesverfassungsgericht [BVerfG] [Federal Constitutional Court] Jan. 15, 2015, 35 STRAFVERTEIDIGER [StV] 269 (270), 2015 (Ger.).

${ }^{79}$ See STPO $\$ 273$, para. 1a, sentence 3 .

${ }^{80}$ See Jahn \& Kudlich, supra note 2 , at $\$ 257 \mathrm{c}$ margin no. 3.

${ }^{81} I d$. at $\$ 243$, para. 4 .

${ }^{82} \mathrm{See}$ Bundesverfassungsgericht [BVerfG] [Federal Constitutional Court] Jan. 15, 2015, 35 STRAFVERTEIDIGER [STV] 269 (270), 2015

${ }^{83}$ See Folker Bittmann, Die kommunikative Hauptverhandlung im Strafprozess, 66 NeUE JURISTISCHE WOCHENSCHRIFT 3017, 3018 (2013).

${ }^{84}$ See Thomas Fischer, in Verhandlungen Des 68. DeUtschen Juristentages Berlin 2010: BAND II/2: SitZUNGSBERICHTE-DisKusSION UND BESCHLUSSFASSUNG (2010).
} 
Verständigung has not been adequately documented, that implies that there was an illegitimate or even illegal deal, which is due to the incentive for the defendant provided by the upper sentencing limit indicated as part. ${ }^{85}$

What an insistence on overly ambitious transparency and documentary requirements does is ultimately approximate the rules of the Verständigung with those of a classical adversarial trial and thus virtually deprive the Verständigung of its scope of practical application. ${ }^{86}$ In particular, you lose what the former Berlin-based criminal judge Friedrich-Karl Föhrig has, long before the Verständigungsgesetz had even been enacted, described as the willingness of the judge to give "bread, rather than stones." ${ }^{77}$ That is to say that there needs to be a forum where the "formalised dissent" 88 of a regular adversarial trial is discarded for the benefit of an open style of communication about the respective perspectives on the state of the proceeding. In doing so, the judge becomes less of a proverbial sphinx. But this does not mean that he engages in a horse-trade with justice for the sole objective of time-saving. A confession that is made in such a context which is, at least in part, motivated by an assurance to reduce the sentence that has previously been given by the court does not, in our view, significantly differ from a confession that the defendant makes upon the advice of his legal counsel, who gives such advice with his client's best interests in mind. $^{89}$

Consequently, the option of negotiating agreements, as envisaged by the Verständigungsgesetz, is hardly used anymore-and the hypothesis that the restrictive approach of the jurisprudence incentivizes the circumvention of the law does not seem far-fetched.

\section{Failed Formalization-New Tendencies Towards Informalization?}

\section{Initial Empirical Observations Since March 19, 2013}

The initial empirical findings on the matter indicate that the negotiation of agreements that takes place within such a normatively incoherent legal framework creates application problems.

In 2012, a survey conducted by Altenhain, Dietmeier, and May, found that more than fifty percent of the members of the status groups involved in criminal proceedings-judges, prosecutors, defendants, and defense attorneys - are terminating more than fifty percent of all criminal proceedings by means of informal agreements with no regard for the regime of the Verständigungsgesetz. ${ }^{90}$ The Federal Constitutional Court has taken these quite shocking findings very seriously in its leading judgment of March 19, 2013. But this did not lead it to the conclusion that the aforementioned failure of protective mechanisms is necessarily inherent in Section 257c of the German Code of Criminal Procedure ${ }^{91}$ itself, which would lead to the unconstitutionality of the provision. While it did not immediately follow from the deficient enforcement of the Verständigungsgesetz that this law was unconstitutional, trial court practice would have to be continuously monitored in order to establish whether there is a considerable degree of transgressions against the law. The substantive and procedural precautions of the Verständigungsgesetz should prove to be insufficient as regards the elimination of said enforcement deficit and thus fulfill the constitutional requirements applicable to negotiated agreements by taking appropriate measures because otherwise, an unconstitutional state of affairs would ensue. And this is where we enter the

\footnotetext{
${ }^{85}$ See 133 BVERFGE 168 (223 f.).

${ }^{86}$ See Patricia Rabe, Das Verständigungsurteil des Bundesverfassungsgerichts und Die NotwendigKeit VON REFORMEN IM STRAFPROZESS 3 (1st ed. 2017).

${ }^{87}$ Friedrich-Karl Föhrig, Kleines Strafrichter-Brevier: Oder: Der ÜBerlastete Strafrichter? WegWeiser Zur ZÜGIGEN URTEILSFINDUNG 37 (2d ed. 2013).

${ }^{88}$ Winfried Hassemer, Konsens im Strafprozeß, in De GruYter Recht, Festschrift FÜr Rainer Hamm 171, 187 (Regina Michalke et al. eds., 2008).

${ }^{89}$ See FÖHRIG, supra note 87 , at 37.

${ }^{90}$ See Karsten Altenhain, Frank Dietmeier \& Markus May, Die PraXis der Absprachen im Strafverfahren 36 (2013).

${ }^{91} \mathrm{STPO} \$ 275 \mathrm{c}$.
} 
equation. As part of the research project entitled "Evaluation of the Provisions of the Verständigungsgesetz in Criminal Proceedings" that runs through $2020,{ }^{92}$ we are examining if, and to what extent, the enforcement deficit has persisted after the 2013 judgment of the Federal Constitutional Court, using different empirical methods such as the analysis of files and expert interviews. Given that we are still right in the middle of the stage of the project where we are collecting data, there are, as of now, only limited and, in any case, no definitive results yet.

What can be said at this point is that the scholarly analysis of the case law, which has been handed down by the Federal Court of Justice and all twenty-four State Courts of Appeal, is that the Federal Constitutional Court's seminal 2013 decision at least confirms that there is a strong focus on provisions that require transparency and documentation. This is particularly apparent in Section 243 paragraph 4, namely the first and second sentences of the Code of Criminal Procedure. ${ }^{93}$ They form the lion's share of procedural complaints that reach the appellate courts. Out of a total of 252 appeals where the appellants relied on infringements of provisions related to negotiated agreements, 236 were procedural complaints, or 93.7 percent, whereas only sixteen, or 6.3 percent, were substantive complaints. In 155, or sixty percent, of the cases, the appellants complained about a violation of obligations of transparency and documentation. In thirty-five cases, or 13.6 percent, the appellants complained about violations of the provisions on procedural equality of arms, while nineteen cases, or 7.4 percent, concerned violations of the court's duty to establish the facts. There were no complaints regarding the discussion of the state of the proceeding. Regarding the cases where higher courts held that infringements were committed, infringements against transparency and documentary obligations topped the list with fifty-five percent. The percentage of cases where the existence of an "informal agreement" was confirmed is only 3.7 per cent.

So far, the existing statistical analysis has not pointed towards any tendency among courts of appeal to interpret Section 344 paragraph 2 of the German Code of Criminal Procedure in such a manner that would make it harder for appellants to lodge procedural complaints due to unrealistically high requirements concerning the substantiation of their complaints. The same applies to the judicial technique to leave open the question of whether a procedural infringement occurred with the justification that the causality of the invoked infringement for the decision of the court of first instance could be ruled out. Whether there are differences in the application between the individual provisions upon closer inspection, it will become clear over the course of the remainder of our project.

What is also interesting is that the defendants bring the vast majority of appeals against judgments that are based on negotiated agreements. Despite the fact that the Federal Constitutional Court explicitly noted in its aforementioned 2013 decision that it falls to the prosecution to maintain the legality of the negotiation, the number of appeals lodged by the prosecution is low. There is, however, another tendency that is just as noticeable as it is troubling: Negotiated agreements are becoming increasingly rare. In 2017, only 0.62 percent of all cases before Magistrates' Courts, the lowest tier of criminal trial courts, were concluded with a negotiated agreement; therefore, one could speak of "dead" procedural law, as far as the Verständigungsgesetz is concerned. Before Regional Courts, the next tier of criminal trial courts, it was 7.28 percent of cases. ${ }^{94}$ The number of appellate decisions that had to deal with negotiated agreements has also been steadily declining after the Federal Constitutional Court decision of March 19, 2013, following a brief rise that lasted until the first quarter of 2015.

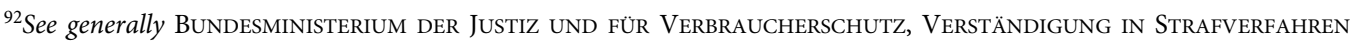
(2018), https://www.verstaendigung-in-strafverfahren.de (last visited July 7, 2020).

${ }^{93} \mathrm{See}$ STPO $\$ 243$, para. 4, sentences $1,2$.

${ }^{94} \mathrm{Cf}$. STRAFGerichte - FACHSERIE 10 ReIHe 2.3, supra note 4, at 24, 62.
} 
The most recent judicial data ${ }^{95}$ does, however, show that in approximately a third of all cases, the prosecution was considered to be "deserving of sanctions" in the broadest sense, and a termination of the proceeding occurred by means of a preferment of public charges in exchanges for the imposition of conditions ${ }^{96}$ or by applying for the imposition of a penal order. ${ }^{97}$ In this regard, we will dedicate particular attention to whether proceedings with negotiated agreements, on the one hand, and terminations in the preliminary proceeding in accordance with Section 153a of the Code of Criminal Procedure, on the other hand, are broadly similar. And, beyond that, which situations trial courts are inclined to agree to a dispensation within terms of Section 153a of the Code of Criminal Procedure and when they prefer negotiated agreements. Additionally, the underlying question of whether, pursuant to Section 153a of the Code of Criminal Procedure, dispensations with court actions used as a means to circumvent the restrictive legal framework envisaged in Section 257c of the Code of Criminal Procedure, will also be of relevance for the remainder of our research project through 2020.

\section{Tendencies to Shift the Focus Forward to the Preliminary Proceeding}

Finally, the number of terminations of proceedings by means of the imposition of conditions, or by penal order, which is high when compared to negotiated agreements, could be emblematic of a further, lasting change of informal practice: The increasing relevance of the preliminary proceeding. For three decades, it has, convincingly, been argued that the trial no longer forms the heart and the climax of a criminal proceeding; instead, the focus has shifted to the preliminary proceeding. In years past, the preliminary proceeding served to confirm a tentative suspicion to the point where there was a degree of basic plausibility - it used to be preparatory and preliminary in nature. These days, it seems to be more about the decision, if, and for what reason, a court action can be dispensed with. This tendency is enhanced by Section 160b of the German Code of Civil Procedure, which provides that the prosecution "may discuss the status of the proceedings with the participants, insofar as this appears suitable to expedite the proceedings." 98 In this context, "expedite" does not necessarily translate as "advancing the proceeding so that a public charge can be brought." ${ }^{\prime 9}$ On the contrary, as the legislative materials to the provision explicitly state, the termination of the proceeding forms a legitimate objective of these discussions. The pacifying effect of a judgment, which helps to solve the social conflict caused by a criminal offense, is progressively replaced by the mere opening of an investigation. The act of opening an investigation itself has a strong general preventive effect, as we know from the proceedings against former German Federal President, Christian Wulff, and former Member of the German Parliament, Sebastian Edathy, as well as from the entire field of economic criminal law. It symbolizes the resolve on the part of law enforcement authorities and proves that not only are the "little guys" subject to punishment, but law enforcement is also gaining an increasingly punitive character.

The termination of proceedings during the preliminary stage is of great practical relevance, particularly in the field of economic and tax crimes, where the limitations of the criminal justice system have become particularly apparent in the face of the complexity of large-scale proceedings. These are the cases where it seems that a consensual solution is, in fact, in the best interest of the accused. There is a stigmatization of the defendant that goes hand in hand with the opening of a criminal trial-especially where the media is involved. There is also a phenomenon that has been summarized with the sentence "semper aliquid haeret," according to which, even in the case of an

\footnotetext{
${ }^{95}$ See id. at 28, 66; STRAFGERICHTE - FACHSERIE 10 ReIHe 2.6, supra note 4, at 26; Felix Boomer et. al., Alternativ-Entwurf Abgekürzte Strafverfahren im Rechtsstaat (AE-ASR): Entwurf eines Arbeitskreises Deutscher, österreichischer und Schweizerischer Strafrechtslehrer, 166 GOLTDAMMER'S ARCHIV FÜR STRAFRECHT 1, 4 (2019).

${ }^{96} \mathrm{See} \mathrm{STPO} \$ 153 \mathrm{a}$.

${ }^{97}$ Id. $\$ 407$.

${ }^{98}$ Id. $₫ 160 \mathrm{~b}$.

${ }^{99}$ See Jahn, supra note 32 , at 42 .
} 
acquittal, "something always sticks." 100 Finally, there are costs associated with defending against criminal allegations. All of this should mean that, on balance, there is a strong incentive for the defendant to obtain a decision that terminates the proceeding at the preliminary stage-aside from the ability to avoid pre-trial custody. Most importantly, the institution of a preliminary proceeding itself directly affects the personal legal sphere of the accused. To name but a few examples: The institution of a preliminary criminal proceeding leads to the suspension of pending approval proceeding that a prospective attorney has to pass in order to be admitted to the bar, pursuant to Section 10 paragraph 1 of the Federal Attorney Act (Bundesrechtsanwaltsordnung), ${ }^{101}$ to the suspension of pending naturalization proceedings, pursuant to Section 12a paragraph 3 of the Nationality Act (Staatsangehörigkeitsgesetz), ${ }^{102}$ to the defendant's inability to serve as a Schöffe (lay judge) in legal proceedings, pursuant to Section 32 Nr. 2 of the Courts Constitution Act (Gerichtsverfassungsgesetz), ${ }^{103}$ or-indirectly-the institution of disciplinary proceedings against public officials, pursuant to Section 17 paragraph 1, in the first sentence of the Federal Disciplinary Act (Bundesdisziplinargesetz), ${ }^{104}$ the refusal of payments by insurance companies with reference to pending preliminary proceedings as per Section 61 of the Insurance Contract Act (Versicherungsvertragsgesetz), ${ }^{105}$ and much more.

Under the current transparency regime as developed by the case law, which is said to exhibit "a rigour ... that would turn every Spanish grand inquisitor green with envy," 106 there is hardly any space left to fulfill the need for informality. Accordingly, these processes are shifted back into the preliminary proceeding. In this context, the motto is: "Whatever you take away from them in one stage of the proceeding, practitioners will simply reclaim in another." ${ }^{107}$ With the increase in the informal termination of criminal proceedings during the preliminary stage, we enter into a space where the defendant enjoys fewer procedural guarantees. Karl Peters' famous observation that the preliminary proceeding is "a fork in the road that determines whether the judgment will ultimately be right or wrong" 108 no longer holds true-figuratively speaking, right or wrong, judgments are already rendered in the preliminary proceeding.

\section{Conclusion and Perspectives for A Potential Reform}

Tendencies towards an informalization create uncertainty-particularly in the realm of criminal law. We are justified in approaching them critically, where they form part of the wider phenomenon of the erosion of the procedural rights of the accused. The jurisprudence paints the dark image of a "closing of the ranks' between the court, the prosecution and the defence that unfolds in secret" that the defendant needs to be protected against. ${ }^{109}$ This must not obscure the imbalance

${ }^{100} \mathrm{Cf}$. Matthias Jahn \& Fabian Meinecke, Prominentenstrafrecht: ein Paradigma des modernen Prozesses, in FESTSCHRIFT FÜR ReINHOld SCHLOTHAUER 129, 133 (Stephan Barton et al. eds., 2018).

${ }^{101}$ Bundesrechtsanwaltsordnung [BRAO] [The Federal Lawyers' Act], Jan. 8, 1959, BGBL III at $\$ 303-8$, last amended by Gesetz [G], Dec. 12, 2019, BGBL at 2602, \$10, para. 1, https://www.gesetze-im-internet.de/brao/BJNR005650959.html (Ger.).

${ }^{102}$ Staatsangehörigkeitsgesetz [STAG] [Nationality Act], Jul. 22, 1914, BGBL III at 102-1, last amended by Gesetz [G], Nov. 20, 2019 BGBL at 1626, $\$ 12$ a, para. 3, https://www.gesetze-im-internet.de/stag/BJNR005830913.html (Ger.).

${ }^{103}$ Gerichtsverfassungsgesetz [GVG] [Courts Constitution Act], May 9, 1975, BGBL I at 1077, last amended by Gesetz [G], Jul. 8, 2019, BGBL I at 1002, \$32, Nr. 2, https://www.gesetze-im-internet.de/gvg/BJNR005130950.html (Ger.).

${ }^{104}$ Bundesdisziplinargesetz [BDG] [Federal Disciplinary Act], Jul. 9, 2001, BGBL I at 1510, last amended by Gesetz [G], Oct. 19 , 2016, BGBL I at 2362, §14, para. 1, sentence 1, http://www.gesetze-im-internet.de/bdg/BJNR151010001.html (Ger.).

${ }^{105}$ Versicherungsvertragsgesetz [VVG] [Insurance Contract Act], Nov. 23, 2007, BGBL I at 2631, last amended by Artikel 6, May 19, 2020, BGBL at 1018, §61, https://www.gesetze-im-internet.de/vvg_2008/BJNR263110007.html (Ger.).

${ }^{106}$ Bernd Schünemann, Überfordert die Komplexität der Wirklichkeit die Juristen?, 34 WISTRA: ZEITSCHRIFT FÜR WIRTSCHAFTS- UND STEUERSTRAFRECHT 164, 164 n.3 (2015).

${ }^{107}$ See Jahn, supra note 32 , at 49.

${ }^{108}$ Karl Peters, Fehlerquellen im Strafprozeß. Eine Untersuchung der Wiederaufnahmeverfahren in der Bundesrepublik Deutschland, Band 2: Systematische Untersuchungen und Folgerungen 299 (1972).

${ }^{109}$ Bundesverfassungsgericht [BVerfG] [Federal Constitutional Court] Jan. 15, 2015, 35 STRAFVERTEIDIGER [StV] 269 (270), 2015 
of power, which is potentially even accentuated by the formalization of the informalization stipulated in the Verständigungsgesetz.

Nevertheless, this must not distract from the structural power asymmetries of inquisitorial proceedings and the insufficient reflection of the influence of the preliminary proceeding, which is discussed under the headlines of "inertia effect"110 or "confirmation bias." 111 It is just as likely that the "closing of the ranks," which is viewed so critically in the legal literature, might occur between the court and the prosecution. This is inherent in the very structure of the inquisitorial proceeding because the court has taken note of the investigation file compiled by the prosecution when it makes its decision to open a trial. The prosecution has, in reality, already documented the results of the investigation in a manner that is heavily influenced by the initial hypothesis of the law enforcement authorities and the prognosis that a guilty verdict is more likely than an acquittal. Thus, there is a large risk that the results of the investigation are interpreted in a broader manner that confirms law enforcement's initial hypothesis.

The worst-case scenario is that of merely formal consent to a conviction in the vein of US-style plea bargaining, to which the defendant is forced to submit in light of the enormous discrepancy between the expected sentence, if he agrees to participate in the plea bargaining, in comparison to what he would face if he did not. This is not true consent. This is a mere concession. ${ }^{112}$

In order to avoid this imbalance of power, it is imperative to design the preliminary proceeding in such a way that it can be both adversarial and participatory in nature. ${ }^{13}$ Critically, this entails, amongst other things, beefing up the rights of the defense at this stage of the proceeding, making the fact-finding process truly adversarial, as well as granting the accused the right to request that an investigation be conducted and to request audio-visual recordings of all police interrogations. Achieving a real balance of power (Waffengleichheit), in this stage of the trial, is a subject de lege ferenda of its own. ${ }^{114}$ Lastly, the accused could be furnished with the right to challenge the investigation itself - that is to say, legal recourse against being made the subject of a criminal investigation. The reason this idea of comprehensive "regulated self-regulation" has not been put into practice in criminal proceedings could be that the role of the accused as an equal party requires some adjustment.

\footnotetext{
${ }^{110}$ Bernd Schünemann, Information über das Vorverfahren und die Befugnisse des Richters in der Hauptverhandlung aus deutscher Sicht, in Peter lang GmbH, Die strafprozessuale HauptVerhandlung zwischen INQUisitorischem und ADVERSATORISCHEM Modell 91, 99 (Friedrich-Christian Schroeder \& Manuchehr Kudratov eds., 2014).

${ }^{111}$ Petra Velten, Das Verhältnis von Ermittlungs- und Hauptverfahren - Der lange Arm des Ermittlungsverfahrens, in

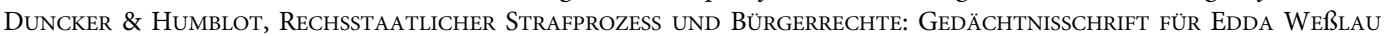
391, 397 (Felix Herzog, Reinhold Schlothauer \& Wolfgang Wohlers eds., 2016).

112 See Trüg, supra note 34, at 366.

${ }^{113}$ Matthias Jahn, Das partizipatorische Ermittlungsverfahren im deutschen Strafprozess, 115 ZEITSCHRIFT FÜR DIE GESAMTE STRAFRECHTSWISSENSCHAFT 815, 821 (2003).

${ }^{114}$ See Jahn, supra note 32, at 55; Schmitt-Leonardy, supra note 5, at 225.
} 